\title{
Socially Responsible Consumer Behavior: The Case of Organic Food in Sonora, Mexico
}

\author{
Carlos G. Palafox ${ }^{1}$, Joel E. Espejel ${ }^{1}$, Dulce S. Elizande ${ }^{1} \&$ Melissa F. Leon $^{1}$ \\ ${ }^{1}$ School of Economics, University of Sonora, Sonora, Mexico \\ Correspondence: Carlos G. Palafox, School of Economics, Hermosillo, SON., Mexico. Tel: 52-662-259-2167.
}

Received: June 5, 2016

Accepted: June 21, 2016

Online Published: September 2, 2016

doi:10.5430/ijba.v7n5p36

URL: http://dx.doi.org/10.5430/ijba.v7n5p36

\begin{abstract}
The main objective of this investigation is to analyze and evaluate the Socially Responsible Consumer (SRC) in the cities of Hermosillo and Obregón, Sonora, Mexico. We wanted to identify their purchasing, consumption and attitude profiles. To respond to the stated objective, 278 questionnaires were applied, 183 were applied to consumers in Hermosillo and the remaining 95 to consumers in Obregon city. For the statistical analysis of the data the chi-squared test $\left(X^{2}\right)$ was used to establish descriptive and bivariate comparisons of the results. It was learned that the young consumers of these cities have no knowledge about Socially Responsible Consumption; moreover, consumers do not feel inclined to buy organic food or environmentally friendly products, neither do they search for products that benefit their finances and environment or otherwise cause the least negative possible impact. Therefore, it is essential that educational comprehensive programs for strengthening responsible consumption and care for the planet be designed in the face of globalization.
\end{abstract}

Keywords: socially responsible consumer, organic food, public policies

\section{Introduction}

Over time the subject of globalization has been directly influencing the lives of people, that is the reason why current methods of consumption and production have become unsustainable, thereby causing the gradual deterioration of the planet. Social crisis and environmental protests are clearly seen around the world day by day, more and more news about the effects that the current unsustainable development has on nature and hence in humans (Palanco, 2009).

Responsible consumption is defined as "the choice of products and services, based not only on quality and price, but also on their social and environmental impact, taking into account the manner the company produces" by the Ecology and Development Foundation, FUNED (2011). For the past few decades, institutions and organizations have been debating the issue and are seeking solutions to stop and reverse the problem that caused the unsustainable consumption and accelerated production in some countries. To that end, the effects of the models that have been practiced over time need to be widely known.

Currently, consumers have started to become aware of the reality facing a crisis that dismays the world and which includes political, social, and ethical issues, among others. These are the situations that we should work on, and because of that the participation of society, the government and businesses are needed, to form a socially responsible system, since "they are all consumers" (Salas, 2015).

However, the lack of education and information in the population is an issue that needs special emphasis. The leading actor of this analysis is the consumer, being the last link in the chain of solidarity and the only one capable of improving living conditions for the future of human beings, with their purchasing power. When there's responsible consumption, importance is given to a number of factors, among them social and ecological conditions in which the products were elaborated, not just their price. For this reason, the purpose is to introduce a new type of consumer, described as Socially Responsible Consumer, which is the primary author of responsible and sustainable consumption.

In Mexico it is not well known what a SRC is, yet according to a survey from "The Global Socially Conscious Consumer" done by Nielsen (2012), this social individual is making presence in the country and although the practice of sustainable consumption models are slowly becoming known, more and more people are informing themselves of this issue. 
The investigation focuses on the importance of being a Socially Responsible Consumer and also on finding the type of consumer that already exists in the two major cities of Sonora, by looking for purchasing and consumption costumes / patterns / practices as well as attitudes related with responsible consumption

\section{Literature Review}

\subsection{Socially Responsible Consumer}

According to Roberts (1995), there is a difference between the definition of Socially Responsible Consumer Behavior (SRCB) and Ecologically Conscious Consumer Behavior (ECCB). As for the SRCB, extensive research has been done in which different characteristics were detected, purchase and consumption profiles, and marketing strategies (e.g. Webster, 1975; Ha-Brookshire and Hodges, 2009) that have impact on Corporate Social Responsibility (CSR) (e.g. Mohr, Webb and Harris, 2001; Ellen, Webb and Mohr, 2006; Becker-Olsen, Cudmore and Hil, 2006; Len, Scott Cato, Keenoy, and Smith, 2007; Webb, Mohr and Harris, 2008; Ditlev-Simonsen, 2010; Manning, 2013). In the case of the ECCB, scientific studies that reveal the importance behavior and attitudes have on green consumers have been developed (e.g. Roberts, 1996; Straughan and Roberts, 1999; Diamantopoulos et al., 2003; Carrete et al., 2012). This research is focused on the theoretical concept of SRCB.

The Socially Responsible Consumer (SRC) is a new citizen, a more critical and selective individual, preferring sustainable products and services of organic nature, which support social and ethical causes. According to Mohr, Webb and Harris (2001), this consumer is referred to as a Socially Responsible Consumer that tries to purchase products from companies that help society. By which, it is understood that there is a relationship of affinity for Socially Responsible Companies (ESR/CRS) (Webb, Mohr and Harris, 2008), which meshes social solidarity and economy, involved in a Fair Trade.

The SRC is a person who informs himself and investigates the various goods and services offered in the market; and from his analysis, makes decisions about which product is suitable, not only for his benefit but also in support of environmental, ethical and social causes (Roberts, 1993). Although the profile analysis of a solidary and responsible consumer has already been done, as well as the study of demographic and personal characteristics of individuals (Webster, 1975), a more valuable approach would be to target consumers based on their personal interests, and to communicate different socially responsible efforts to different groups (Oberseder et al., (2011) in Davis 2013).

SRC are those who perform best practices in relation to their acts of purchase, besides acquiring sustainable products and services that respect social and ethical guidelines, they are also willing to pay an additional cost for them (Laroche, Bergeron, and Barbaro-Forleo, 2001). This new group consists mainly of young people who use social networks and technology as a tool to stay informed, in addition to their interest on environmental causes, education and the fight against hunger (Nielsen, 2012).

Therefore, this new leading actor in the market and trade has the attitude to strengthen and encourage consumption and purchase habits that promote sustainable development in their surroundings. They are interested in having free access to information about companies or products offered in the market to be able to make an informed decision about which goods to obtain, the latter in order to support ethical and social causes, as well as important improvements in science education, technology and mathematics, eradication of poverty, and with more interest shown towards environmental sustainability (Nielsen, 2012).

In its broadest form, the social responsibility of consumers may be defined as the conscious and deliberate choice to make consumption decisions based on morals and personal beliefs (Roberts, 1995). This includes two basic components: the first is an "ethical" one, which is related to the fundamental importance of non-traditional and social elements of a company's products and business processes; the second component is "consumerism" which implies that the preferences and desires of the consumer segments are partly responsible for the growing influence of ethical or social factors (Devinney, 2006; Devinney et al., 2006).

The profile of a Socially Responsible Consumer is made up by different characteristics, this individual has to primarily be an informed consumer, someone who knows and uses quality and good price products and services (Abrantes, Gonçalves and Dias de Faria, 2010), must be a conscientious person that knows his rights and obligations in addition to the environmental and social impact that their purchases cause. Based on that alone, choose products that meet his needs. This individual is also a supportive and sustainable consumer preferring products of Socially Responsible Companies (Ellen, Webb and Mohr, 2006), and consumes local products always trying to reduce the environmental and social footprint of their purchases, promoting responsible consumption (Salas, 2012). 


\section{Problem Statement}

In recent years, some of the issues that have gained greater relevance are the creation of sustainable consumption patterns, socially responsible companies (Mohr, Webb and Harris, 2001), and types of alternative or sustainable marketing, including "Fair Trade" and a new type of consumer with socially responsible characteristics that figures essentially in these approaches.

The consumer lacks information to carry out such practices and to become an individual with responsible characteristics (Roberts, 1996). Nonetheless, they are slowly acquiring more environmental commitments and new habits that help preserve the planet as part of a socially responsible generation (Salas, 2012). It is becoming essential to analyze the purchasing decisions they make and the influence that the environment has on them.

Thus it is very important to be informed on how the product you are buying is produced, if in the manufacturing of products social and micro environmental standards were respected, such as child labor, employment discrimination, if there was a fair payment to workers; in addition to the product being environmentally friendly, and this way promoting the importance of doing businesses with respect for human dignity and care for the planet. Also, letting the consumer know the benefits of practicing socially responsible habits. Nevertheless, this is not the job of a single party, but of consumers, institutions and companies, that have to work together to achieve a system of social and environmental responsibility.

\subsection{Research Objectives}

To solve the problem stated it is relevant to consider the following research objectives:

- Identify the profile of the Socially Responsible Consumer in the cities of Hermosillo and Obregon, Sonora.

- To know the sociodemographic, purchasing and consumption habits, and psychological attitudes of the Socially Responsible Consumers in Hermosillo and Obregon City, Sonora.

\subsection{Research Questions}

Following the theoretical approaches on responsible consumption, and wondering what happens to the social behavior of consumers in Sonora, the following questions arise:

- What is the profile of the Socially Responsible Consumer in Sonora?

- What are the sociodemographic characteristics, purchasing and consumption habits, and psychological attitudes of the Socially Responsible Consumers in Hermosillo and Obregon City, Sonora?

\subsection{Hypothesis}

This study is positioned as one of the first studies undertaken on this subject in the State of Sonora. To meet the objectives and research questions based on theoretical arguments and scientific findings the following hypotheses formulated:

H1: A new consumer profile with socially responsible characteristics exists in Sonora.

H2: The consumer seeks to inform himself to make purchases that benefit their environmental and economic environment or otherwise cause the least negative impact possible.

H3: Consumers are inclined to organic and environmentally friendly products.

\section{Methodology}

In this section, the methodological aspect is developed in order to analyze and to make comparisons between attitudes and behaviors of consumers to purchase new practices and responsible consumption characteristic. The research design is not experimental transactional or transversal, due to its temporal dimension, where data was collected at a single time, where variables were described and their impact or interaction were analyzed in samples of populations subject to study. In addition, an empirical study in the state of Sonora was done; specifically, a random sampling was applied to the inhabitants of the cities of Hermosillo and Obregon.

\subsection{Research Design}

With the objective to analyze the behavior and attitudes of consumers towards a more conscious consumer behavior, which involves responsible purchasing practices. A simple random sampling was conducted in the cities of Hermosillo and Obregon, a sampling error of $6 \%$ was assigned to both cities, a total of 278 surveys were applied. Subsequently, based on the proportion of the populations 183 surveys were assigned to Hermosillo and 95 to Obregon City. The surveys were applied during the months of December 2014 and January 2015, to people over 18 
years of age, who were in public places such as plazas, shopping centers, universities, and other social areas. After randomly applying the surveys, a database was created using IBM SPSS 20.0 software, where the information from the surveys was collected, following by codifying the data, in which descriptive and bivariate analysis were created using the information, and the chi-squared test for comparisons and relations of the results.

\subsection{Data Collection}

A questionnaire that consisted of 19 interrogatives, 4 sections and 2 control questions (one of the beginning and the other at the end) was designed. The structure of the statistical tool that was used for the collection of the information is displayed as follows (Roberts, 1995; Roberts, 1996):

- "Sociodemographic Characteristics", made up of five questions related to the, age gender, education level, and social class, also an approximate of their monthly income, all this to conclude the type of market in which they have more product acceptance, trying to prevent significant bias in the results of the research data collected by the surveys. In general, each section of the questionnaire was composed of dichotomous and polytomous questions.

- "Purchasing Habits", the practice of consumers in the market was analyzed, to see whether users are willing to buy local or domestic products and find out whether those products should be developed in compliance with certain measures such as environmental and social ones, in addition to seeking data as to how they inform themselves when making a purchasing decision.

- "Consumption Habits", this section seeks to get information about the preferences between products and the most important features for consumers in products of equal price and quality, exhibiting characteristics to infer whether that individual is likely to be a socially responsible consumer or not, this section is composed of two questions.

- "Attitudes/Psychological Characteristics", in this section the willingness of consumers to consume products that are produced sustainably and/or protect the environment are sought, as well as other causes such as supporting education and the fight of hunger.

\subsection{Sample}

To calculate the sample of both cities, they were defined as infinite populations, being 469,344 inhabitants in Hermosillo and 296,500 inhabitants in Obregon City being over 18 years old (INE, 2013), taking as unknown the proportion of people with attitudes or characteristics of a Socially Responsible Consumer in both sectors; For this reason the test samples were estimated in relation to a simple random sampling for an infinite population, using the following formula:

$$
n_{\circ}=\frac{k^{2} P Q}{e^{2}}
$$

Where:

$\mathrm{P} . \mathrm{Q}=$ the heterogeneity of the population.

$\mathrm{K}=$ trust desired $(95.5 \%=2)$.

$\mathrm{e}=$ error $(6 \%$ For Hermosillo and Obregon).

Given the characteristics of the study, this sample was estimated appropriate and representative for exploratory research purposes. Table 1 presents the data sheet. 
Table 1. Data Sheet of the consumer survey

\begin{tabular}{|c|c|c|}
\hline \multicolumn{3}{|l|}{ Consumer Survey } \\
\hline Characteristics & Hermosillo & gón \\
\hline Population over 18 & 469344 & 296500 \\
\hline Sample size & 183 & 95 \\
\hline Sample selection & \multicolumn{2}{|c|}{ Simple Random } \\
\hline Information gathering & \multicolumn{2}{|c|}{ Personal Survey } \\
\hline Place & Hermosillo & Obregón \\
\hline Stratification criteria & \multicolumn{2}{|c|}{ Age } \\
\hline Error & \multicolumn{2}{|c|}{$0.06 \%$} \\
\hline Trust & \multicolumn{2}{|c|}{$0.95 \%$} \\
\hline Date of fieldwork & $\begin{array}{l}\text { During the month of } \\
\text { December } 2014\end{array}$ & $\begin{array}{l}\text { During the month } \\
\text { of January } 2015\end{array}$ \\
\hline Pilot & \multicolumn{2}{|c|}{ During the month of September } \\
\hline
\end{tabular}

Source: Self creation

\section{Data Analysis}

The analysis of the collected information is developed using the IBM SPSS 20.0 software. The statistics were performed as follows: (1) Descriptive analysis (means, modes and frequencies), (2) Question comparisons with the Chi-squared test, (3) Descriptive analysis that specifies characteristics of the sample, and (4) Exploratory analyzes on each set of questions in the survey.

Based on the sociodemographic characteristics of the sample, Table 2 shows that the proportion of women interviewed in both cities is slightly higher than that of men. The average age of consumers is between 18 and 32 , for the two cities, slightly highlighting the segment of 43-47 years in the region of Hermosillo. For the information shown very little difference in percentages between the two cities is noticed, although there is a relationship between income level and perception of status among them, in which an average monthly income for Hermosillo and low monthly income for Obregon is shown. However, there is a contrast with the level of income, because Hermosillo shows a trend that is low to medium and that of Obregon ranges from medium to low. In addition, the educational level displayed in Hermosillo is greater than that of Oregon, so the improved economic situation in the city of Hermosillo is evident.

Table 2. Sociodemographic characteristics

\begin{tabular}{|c|c|c|c|}
\hline Variable & Segment & Hermosillo & Obregón \\
\hline \multirow[t]{2}{*}{ Gender } & Female & $59.70 \%$ & $53.70 \%$ \\
\hline & Male & $40.30 \%$ & $46.30 \%$ \\
\hline \multirow[t]{5}{*}{ Age } & $18-22$ & $23.20 \%$ & $32.00 \%$ \\
\hline & $23-27$ & $19.30 \%$ & $16.80 \%$ \\
\hline & $28-32$ & $13.30 \%$ & $11.60 \%$ \\
\hline & $33-37$ & $9.90 \%$ & $8.40 \%$ \\
\hline & $38-42$ & $6.60 \%$ & $7.40 \%$ \\
\hline
\end{tabular}




\begin{tabular}{cccc}
\hline & $43-47$ & $10.50 \%$ & $8.40 \%$ \\
\hline & $48-52$ & $6.10 \%$ & $6.30 \%$ \\
\hline Monthly & $53-57$ & $5.0 \%$ & $0.00 \%$ \\
\hline Income & 58 o más & $6.10 \%$ & $7.40 \%$ \\
\hline Status & Lower & $26.60 \%$ & $51.60 \%$ \\
\hline & High & $38.60 \%$ & $28.50 \%$ \\
\hline & Middle & $32.0 \%$ & $14.80 \%$ \\
\hline High & $0.0 \%$ & $1.10 \%$ \\
\hline bducation & Middle & $14.40 \%$ & $9.50 \%$ \\
\hline level & Lower-Middle & $61.90 \%$ & $55.80 \%$ \\
\hline & Lower & $18.80 \%$ & $26.30 \%$ \\
\hline & Elementary & $2.20 \%$ & $4.20 \%$ \\
\hline & Middle & $1.10 \%$ & $1.10 \%$ \\
\hline & Higher & $34.80 \%$ & $56.80 \%$ \\
\hline
\end{tabular}

\section{Source: Self creation}

${ }^{a}$ Variable monthly income segment into three strata: low, médium and high. For the low level the income corresponds of 10000.00 or less, for the mddle income stratum 10000.00 to 20000.00 and the high of 20000.00 or more.

${ }^{\mathrm{b}}$ The educational level variable was taken as elementary, middle and upper. Elementary: primary and middle: jr. high and high school. For higher education: college, masters, and doctor's degree.

\subsection{Consumer Buying Habits Characteristics}

Justifying the data obtained from the survey, Obregon has a higher percentage $(80 \%)$ of people who claim to know what a Socially Responsible Consumer is compared with the population of Hermosillo (72.4\%). But when analyzing the control question which referred to the definition of a SRC, the proportion of people who really knew the definition decreased in both cities (Figure 1).

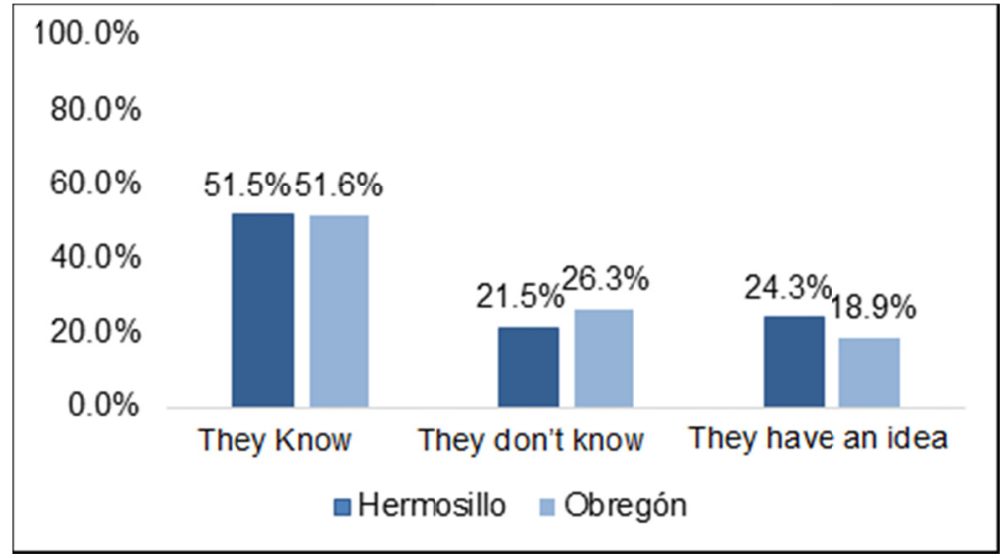

Figure 1. People who know the definition of SRC

Source: Self creation 
In the situation of consumers willing to buy products made in the region to strengthen the local economy, the information collected resulted in a favorable response in both cities with the a percentage higher than $90.0 \%$, although higher proportion in Obregon with $96.8 \%$. However, when related to the question of whether they would be willing to buy organic products at local markets, the percentage in Obregon remained higher $(98.9 \%)$ while in Hermosillo the percentage dropped significantly to $88.4 \%$.

Upon asking consumers if they would purchase products, that would respect environmental guidelines, among others, which would lead to a slightly higher price, most of the people showed inclination towards these products, Obregon standing above Hermosillo with $80.0 \%$ and $74.6 \%$, respectively.

On the question of whether or not users consult any type of information before purchasing a product or service, people mostly answered no. Consumers that do inform themselves before deciding on their purchase are $41.5 \%$ and $50.6 \%$ for Obregon and Hermosillo, respectively. There is a coincidence between Hermosillo and Obregon, between those consumers that only inform themselves through the "labeling" of the products.

Furthermore, consumers who did not consult any information, passed to filter options which are shown in Table 3 .

Table 3. Characteristics by which they are guided

Hermosillo Obregon

\begin{tabular}{|ccc|}
\hline Quality & $55.2 \%$ & $69.5 \%$ \\
\hline Price & $50.8 \%$ & $49.5 \%$ \\
\hline Brand & $37.0 \%$ & $50.5 \%$ \\
\hline Origin & $25.5 \%$ & $31.6 \%$ \\
\hline Recommendation & $23.0 \%$ & $34.7 \%$ \\
\hline Warranty & $16.1 \%$ & $13.7 \%$ \\
\hline Quantity & $12.2 \%$ & $9.5 \%$ \\
\hline Design & $8.8 \%$ & $4.2 \%$ \\
\hline Promotions & $7.2 \%$ & $10.5 \%$ \\
\hline a Other & $1.2 \%$ & $0 \%$ \\
\hline
\end{tabular}

Source: Self creation

${ }^{a}$ Within the variable "others" is: nutritional information, expiration.

The most important attributes that the people are guided by when deciding their purchases were quality, price and brand both cities coinciding, with a minimum difference of the two regions, because the price would be a more important factor for consumers to Hermosillo (50.8\%), while Obregon consumers care more about the brand (50.5\%) than the price $(49.5 \%)$.

Analyzing the level of importance the consumer gives to the "origin" element within the attributes to choose a product at a time of purchase, it is denoted that it is not one of the priority characteristics they seek in a product, with that, the variable origin falls into fourth place weighing between 20 to 30 percent. However, this is contradictory to what was stated in the first questions concerning the purchase made to producers in the region or to purchase products in local markets to strengthen the local economy, where an inclination was shown to support such initiatives, the paradox here is that if these practices are supported is because the place of origin is valued.

Based on the above, for the socially responsible consumer it is very important to learn about the place of origin of the products, as well as by whom it was made, and how production done. In Table 4, the indifference manifested toward the origin variable with a percentage of $25.5 \%$ and $31.6 \%$ for Hermosillo and Obregon shown respectively.

In terms of whether or not consumers take into account the place of origin of the products they consume, apart from the characteristics that helped them acquire their products; it resulted in favorable terms of proportion being in $43.2 \%$ for Obregon and 55.8\% for Hermosillo, which contrasts with the data presented above. In the last part of purchasing 
habits a number of options were given to consumers to know what kind of products they had consumed during the last month and if they were consumed regularly.

The results were that people were more likely to purchase items that were made locally or in the country, regardless of the preference that they manifest, people buy in a higher ratio the local ( $82.3 \%$ Hermosillo and $82.1 \%$ Obregon). However, the data shows that the products with higher indifference were social and/or environmental being these with the lowest percentage, showing 16.6\% in Hermosillo and 21.1\% in Obregon (See Figure 2).

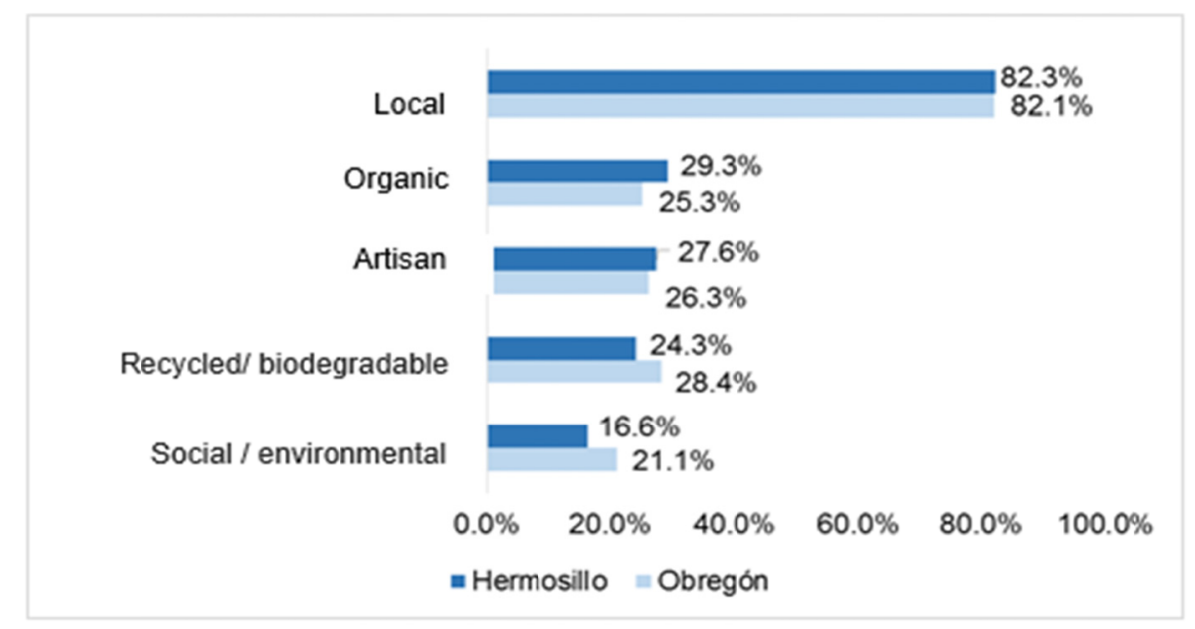

Figure 2. Characteristics of preferred products

Source: Self Creation

${ }^{\text {a }}$ The sum of percentages exceeds one hundred percent because respondents could answer more than one option.

\subsection{Characteristics of Consumption Habits}

In terms of consumption habits, an approach was, based on two products of equal quality and price. The consumer would choose characteristics based on their preference order. According to the results shown in table 4, between two products of equal quality and price between Hermosillo and Obregon, consumers give more importance to the characteristics of origin and to the fact that the products are made from renewable raw material. However, the less important issue according to their selections was the company having a social purpose, design, brand and that the products are biodegradable or recyclable.

Table 4. Important characteristics between two products of same quality and price

\begin{tabular}{|ccc|}
\hline & Hermosillo & Obregón \\
\hline Variables & Mean & Mean \\
\hline Origin & 4.78 & 5.21 \\
\hline Made from renewable raw materials & 4.56 & 4.82 \\
\hline Environmentally friendly & 4.23 & 4.53 \\
\hline Biodegradable and/or recyclable & 4.12 & 4.55 \\
\hline Brand & 3.67 & 3.97 \\
\hline Innovation and design & 3.64 & 3.12 \\
\hline Company with a social purpose & 3.32 & 3.22 \\
\hline
\end{tabular}

Source: Self creation

Note: Values were reversed, measured from 1 to 7 according to importance. 


\subsection{Attitude Characteristics/Psychological Attitudes}

In the section where the consumer psychological attitudes are studied, three issues were looked at in order to analyze the causes considered needing more support, within the following options: environmental sustainability, education, eradication of poverty, global hunger.

Comparing the above study, against the alternatives given to the respondents to choose from as the reasons that they believe consumers are changing the purchasing attitudes they were given the following : for trend, because they want to have a healthier life, because the environment is endangered, because it is cheaper or do not know.

The answers given by consumers were favorable to the education variable in Hermosillo with $35.4 \%$ and $40.0 \%$ in Obregon, followed by fighting hunger with $22.1 \%$ and $24.2 \%$, respectively. Given the opportunity these are the causes consumers would support through their purchases. These causes are the ones they consider a priority if they were given the opportunity to support through their purchases. However, in the second question people believe the new purchasing behavior is because consumers care about the environment and are seeking to implement a healthier lifestyle, result shown in Table 5.

Table 5. Alternatives as to why consumers are changing their consumer attitude

\begin{tabular}{|c|c|c|}
\hline Variable & Hermosillo & Obregón \\
\hline Environment & $60.2 \%$ & $65.3 \%$ \\
\hline Healthier lifestyle & $20.4 \%$ & $23.2 \%$ \\
\hline Trend & $11.0 \%$ & $3.2 \%$ \\
\hline Cheaper & $4.4 \%$ & $4.2 \%$ \\
\hline Don't know & $3.9 \%$ & $4.1 \%$ \\
\hline
\end{tabular}

Source: Self Creation

\subsection{Comparisons: Bivariate Analysis}

In the bivariate analyzes comparative studies of sociodemographic characteristics are performed with the question of whether people know the concept of SRC, with the purpose of locating consumers notion of what a Socially Responsible Consumer is an estimate the latent attitudes population of this type of consumer.

Based on the comparative analysis conducted to populations of Hermosillo and Obregon by test $X_{1}^{2}$ (Chi-squared), it was discovered that Hermosillo consumers find meaningful relationships within the variable income and education level, even though the age characteristic is highlighted with individuals between the ages of 18-32 with a greater understanding of what a SRC is. The consumers that stand out by not having an idea of what a Socially Responsible Consumers is, were the mature population.

However, the situation changes for the characteristics of income and education level, because these two variables have significant relationships, the results show that high-end consumers in Hermosillo have great advantage over the knowledge of what a Socially Responsible Consumer is (40.9\%, Table 6) compared with the population of Obregon (12.2\% Table 7). Middle income individuals have a higher proportion (54.4\%) compared to other income levels and characteristics of "know" and "do not know". 
Table 6. Demographic profile of consumers to the cities of Hermosillo with SRC knowledge

\begin{tabular}{|c|c|c|c|c|}
\hline \multirow{3}{*}{$\begin{array}{c}\text { Demographic } \\
\text { Characteristics }\end{array}$} & \multirow{3}{*}{$\begin{array}{l}\text { Test X / } \\
\text { Chi-squared } \\
\text { (probability } \\
\text { value) } \\
\text { Hermosillo }\end{array}$} & \multicolumn{3}{|c|}{ Concept of a Socially Responsible Consumer } \\
\hline & & Have an idea & Do not know & Know \\
\hline & & Hermosillo & Hermosillo & Hermosillo \\
\hline Age & 0.393 & & & \\
\hline 18-22 & & $34.6 \%$ & $10.3 \%$ & $\underline{23.7 \%}$ \\
\hline 23-27 & & $\underline{22.7 \%}$ & $25.6 \%$ & $16.1 \%$ \\
\hline 28-32 & & $11.4 \%$ & $7.7 \%$ & $14.0 \%$ \\
\hline 33-37 & & $9.1 \%$ & $12.8 \%$ & $8.6 \%$ \\
\hline $38-42$ & & $4.5 \%$ & $7.7 \%$ & $7.5 \%$ \\
\hline 43-47 & & $9.1 \%$ & $10.3 \%$ & $11.8 \%$ \\
\hline 48-52 & & $4.5 \%$ & $7.7 \%$ & $6.5 \%$ \\
\hline 53-57 & & $2.3 \%$ & $5.1 \%$ & $6.5 \%$ \\
\hline More of 58 & & $0.0 \%$ & $12.8 \%$ & $5.4 \%$ \\
\hline Monthly Income & $0.017 * *$ & & & \\
\hline Low & & $20.5 \%$ & $43.6 \%$ & $23.7 \%$ \\
\hline Average & & $54.5 \%$ & $33.3 \%$ & $35.5 \%$ \\
\hline High & & $25.0 \%$ & $23.1 \%$ & $40.9 \%$ \\
\hline Education Level & $0.012 * *$ & & & \\
\hline Elementary & & $0.0 \%$ & $5.3 \%$ & $0.0 \%$ \\
\hline Middle & & $36.4 \%$ & $50.0 \%$ & $30.1 \%$ \\
\hline Higher & & $63.6 \%$ & $44.7 \%$ & $69.9 \%$ \\
\hline
\end{tabular}

\section{Source: Self Creation}

${ }^{a}$ The variables that were significantly different between segments are included only.

${ }^{\mathrm{b}}$ Chi-squared test: ${ }^{* * *},{ }^{* *}$ and $*$ indicates significant association at 1,2 and $10 \%$ respectively.

However, within the population in the city of Obregon data did not show a significant difference, because the proportion of the sample was reduced in relation to the survey population in the city of Hermosillo. The information in Table 7 highlights young people with a better understanding of what a SRC being $55.6 \%$ for those who "have no idea" and consumers who know, denote the ages of $18-22$ years old, $23-27$ and $28-32$ years with $35.4 \%, 18.8 \%$ and $14.6 \%$ respectively.

As for the variables about income and education level, a discrepancy shown in the results obtained in the city of Hermosillo because the information in Table 7 indicates that low-average income consumers are the ones that have a better understanding of the concept; however, people of elementary education are the ones that least know the concept of SRC. 
Table 7. Demographic profile of consumers to the cities of Obregon with SRC knowledge

\begin{tabular}{|c|c|c|c|c|}
\hline Variables & Test X/ & Concept of a & Responsil & onsumer \\
\hline \multirow[t]{2}{*}{$\begin{array}{c}\text { Demographic } \\
\text { Characteristics }\end{array}$} & $\begin{array}{l}\text { (probability } \\
\text { value) }\end{array}$ & Have an idea & $\begin{array}{l}\text { Do not } \\
\text { know }\end{array}$ & Know \\
\hline & Obregón & Obregón & Obregón & Obregón \\
\hline Age & 0.129 & & & \\
\hline 18-22 & & $55.6 \%$ & $12.0 \%$ & $35.4 \%$ \\
\hline 23-27 & & $0.0 \%$ & $24.0 \%$ & $18.8 \%$ \\
\hline 28-32 & & $11.1 \%$ & $4.0 \%$ & $14.6 \%$ \\
\hline 33-37 & & $11.1 \%$ & $12.0 \%$ & $6.3 \%$ \\
\hline $38-42$ & & $11.1 \%$ & $16.0 \%$ & $2.1 \%$ \\
\hline $43-47$ & & $5.6 \%$ & $12.0 \%$ & $8.3 \%$ \\
\hline $48-52$ & & $5.6 \%$ & $12.0 \%$ & $8.3 \%$ \\
\hline $53-57$ & & $0.0 \%$ & $12.0 \%$ & $6.3 \%$ \\
\hline More of 58 & & $5.6 \%$ & $8.0 \%$ & $8.3 \%$ \\
\hline Monthly Income & 0.369 & & & \\
\hline Low & & $64.7 \%$ & $58.3 \%$ & $49.0 \%$ \\
\hline Average & & $17.6 \%$ & $20.8 \%$ & $38.8 \%$ \\
\hline High & & $17.6 \%$ & $20.8 \%$ & $12.2 \%$ \\
\hline Education Level & 0.257 & & & \\
\hline Elementary & & $5.6 \%$ & $0.0 \%$ & $0.0 \%$ \\
\hline Middle & & $55.6 \%$ & $68.0 \%$ & $55.1 \%$ \\
\hline Higher & & $18.9 \%$ & $21.6 \%$ & $59.5 \%$ \\
\hline
\end{tabular}

Source: Self Creation

${ }^{a}$ The variables that were significantly different between segments are included only.

${ }^{\mathrm{b}}$ Chi-squared test: ${ }^{* *},{ }^{* *}$ and $*$ indicates significant association at 1,5 and $10 \%$ respectively.

\section{Results and Discussion}

The Socially Responsible Consumer is a person with specific characteristics, which basically supports three causes: ethical, social and environmental ones. This user is relatively new, because of the current necessities, updated and informed consumers are also needed. Those who inform themselves of what they consume, what to demand, are critical mostly that are aware of the impact their consumption causes in society and the environment, with that, Hypothesis 1 is proved. The study yielded results that there is interest in practices associated with a SRC. Consumers in both regions show preference for products and/or sustainable causes. However, when framing an increase the price of product, they are no longer attractive to consumers and prefer products that are cheaper. Therefore, Hypothesis 3 was rejected, since most consumers do not buy organic products because they are overpriced. 
Another difficulty to generate responsible consumer habits is that the individual is misinformed of the seals and certifications that exist in the products, most are guided by the brand or recommendations as a matter of convenience or time. Currently the existence of a Socially Responsible Consumer in the regions of Hermosillo and Obregon would be considered minimal; since a SRC has to be an individual willing to pay a little more than what would be paid for a product to which he is accustomed. As mentioned, Hypothesis 2 was also rejected, because the consumer is not informed before shopping, he does not know what kind of items are favoring local producers or which have an environmental, economic or social benefit. While most do review seals and labels as a form of information of the products they consume, they usually only do so with items that they usually acquire, and are content with information about the expiration date.

\section{Conclusions}

The purpose of the investigation was to analyze consumer behavior in targeted populations and seek if individuals had social and responsible characteristics in their purchasing and consumption habits or if they gave importance to products that were devolved organically and with social ethic.

The main difficulty this research faces is that unfortunately there is no universal concept accepted by the different authors of what is a socially responsible consumer; also in Mexico topics on Fair Trade and responsible consumption are not well exploited due to lack of awareness on the part of government institutions, universities and society in fostering these production and consumption alternatives. However, despite the difficulties, this type of consumer has been gaining ground in recent years.

Finally, we conclude that although young people have more access to information due to the internet and social networks, most people are not familiarized with the concept of responsible consumption, and therefore to what being a Socially Responsible Consumer implies. While consumers seem to have an idea of what responsible consumption would entail, they don't do it.

\section{Practical Implications}

The reason why consumers don't have a clear idea of what a socially responsible consumer is because of the lack of dissemination of socially responsible products and fostering responsible consumption by the three levels of government. The diffusion of it should be done through the design and implementation of public policies in education that highlight environmental care, with the aim of coordinating efforts to achieve responsible practices in Mexico, in the future. A major contribution of this investigation is that it can serve future research, because as mentioned there is no precedent in the literature, especially on Socially Responsible Consumers in our country.

\section{References}

Abrantes, D., Gonçalves, M., \& Dias de Faria, M. (2010). Corporate social responsibility and consumers' perception of price. Social Responsibility Journal, 6(2), 208-221. http://dx.doi.org/10.1108/17471111011051720

Becker-Olsen, K.L., Cudmore, B.A., \& Hill, R.P. (2006). The impact of perceived corporate social responsibility on consumer behavior. Journal of Business Research, 59, 46-53. http://dx.doi.org/10.1016/j.jbusres.2005.01.001

Carrete, L., Casta-o, R., Félix, R., Centeno, E., \& González, E. (2012). Green consumer behavior in an emerging economy: confusion, credibility, and compatibility. Journal of Consumer Marketing, 29(7), 470-481. http://dx.doi.org/10.1108/07363761211274983

Davis, S.L. (2013). Consumer Social Responsability. En García, A.B (Coord.), La responsabilidad social en el ámbito de la crisis: memoria académica curso 2012-2013 (pp. 237-239). Espa-a.

Devinney, T. (2006). The other CSR: Consumer Social Responsibility. Stanford Social Innovation Review, 30-32. http://dx.doi.org/10.2139/ssrn.901863

Devinney, T., Auger P., Eckhardt G., \& Birtchnell T. (2006). Are consumer sufficiently aware of social product alternatives?. The other CSR: Consumer Social Responsibility, pp. 6. Australia.

Diamantopoulos, A., Schlegelmilch, B.B., Sinkovics, R.R., \& Bohlen, G.M. (2003). Can socio-demographics still play a role in profiling green consumers? A review of the evidence and an empirical investigation. Journal of Business Research, 56(6), 465-480. http://dx.doi.org/10.1016/S0148-2963(01)00241-7

Ditlev-Simonsen, C.D. (2010). From corporate social responsibility awareness to action?. Social Responsibility Journal, 6(3), 452-468. http://dx.doi.org/10.1108/17471111011064807 
Ellen, P.S, Webb, D.J., \& Mohr, L.A. (2006). Building Corporate Associations: Consumer Attributions for Corporate Socially Responsible Programs. Journal of the Academy of Marketing Science, 34, 147-157. http://dx.doi.org/10.1177/0092070305284976

Engel, C.J., Bell, R.L., Meier, R.J., Martin, M.J., \& Rumpel, J.H. (2011). Young consumers in the new marketing ecosystem: an analysis of their usage of interactive technologies. Academy of Marketing Studies Journal, 15(2), 23-44.

FUNED. (2011). Consumo Responsable. Fundación Ecología y Desarrollo, Consultado en septiembre 2014. Retrieved from www.consumoresponsable.org

Ha-Brookshire, J.E., \& Hodges, N.N. (2009). Socially Responsible Consumer Behavior? Exploring Used Clothing Donation Behavior. Clothing and Textiles Research Journal, 27(3), 179-196. http://dx.doi.org/10.1177/0887302X08327199

Laroche, M., Bergeron, J., \& Barbaro-Forleo, G. (2001). Targeting consumers who are willing to pay more for environmentally friendly products. Journal of Consumer Marketing, 18(6), 503-520. http://dx.doi.org/10.1108/EUM0000000006155

Len A., Scott Cato, M., Keenoy, T., \& Smith, R. (2007). Corporate Social Responsibility in Your Own Backyard. Social Responsibility Journal, 3(2), 32-38. http://dx.doi.org/10.1108/17471110710829704

Manning, L. (2013). Corporate and consumer social responsibility in the food supply chain. British Food Journal, 115(1), 9-29. http://dx.doi.org/10.1108/00070701311289858

Mohr, L.A., Webb, D.J., \& Harris, K.E. (2001). Do Consumers Expect Companies to be Socially Responsible? The Impact of Corporate Social Responsibility on Buying Behavior. Journal of Consumer Affairs, 35(1), 45-72. http://dx.doi.org/10.1111/j.1745-6606.2001.tb00102.x

Nielsen. (2012). The Global, Socially Conscious Consumer. The Nielsen Company. Consultado en febrero de 2014. Retrieved from www.nielsen.com/us/

Palanco, L.N. (2009). El consumo en la sociedad y su globalización. Revista Contribuciones a la Economía. Retrieved from http://www.eumed.net/ce/2009b/

Roberts, J.A. (1993). Sex Differences in Socially Responsible Consumers' Behaviour. Psychological Reports, 73, 139-148. http://dx.doi.org/10.2466/pr0.1993.73.1.139

Roberts, J.A. (1995). Profiling Levels of Socially Responsible Consumer Behavior: A Cluster Analytic Approach and Its Implications for Marketing. Journal of Marketing Theory and Practice, 3(4), 97-117. http://dx.doi.org/10.1080/10696679.1995.11501709

Roberts, J.A. (1996). Green consumers in the 1990s: Profile and implications for advertising. Journal of Business Research, 36(3), 217-231. http://dx.doi.org/10.1016/0148-2963(95)00150-6

Salas, C.A. (2010). El consumo responsable en Colombia. Tesis de Grado. Bogotá, Colombia. Retrieved from http://www.javeriana.edu.co/biblos/tesis/economia/tesis206.pdf

Salas, J.A. (2012). Enfoques sobre el consumidor, Marketing New Theories. Consultado en diciembre de 2014. Retrieved from http://marketing-new-theories.blogspot.mx/2012/11/enfoques-sobre-el-estudio-del.html

Straughan, R.D., \& Roberts, J.A. (1999). Environmental segmentation alternatives: a look at green consumer behavior in the new millennium. Journal of Consumer Marketing, 16(6), 558-575. http://dx.doi.org/10.1108/07363769910297506

Webb, D.J., Mohr, L.A., \& Harris, K.E. (2008). A re-examination of socially responsible consumption and its measurement. Journal of Business Research, 61(2), 91-98. http://dx.doi.org/10.1016/j.jbusres.2007.05.007

Webster, Jr., F.E. (1975). Determining the Characteristics of the Socially Conscious Consumer. Journal of Consumer Research, 2(3), 188-196. http://dx.doi.org/10.1086/208631 